\title{
ПСИХОЛОГІЧНА РЕАБІЛІТАЦІЯ ПСИХОСОМАТИЧНИХ ХВОРИХ ПРАЦЕЗДАТНОГО ВІКУ
}

\author{
Галина Мозгова \\ доктор психологічних наук, професор, \\ завідувачка кафедри психосоматики та психологічної реабілітації \\ Національний педагогічний університет імені М.П. Драгоманова \\ 01601, Україна, м. Київ, вул. Пирогова, 9 \\ gala_mozgovaya@ukr.net, https://orcid.org/0000-0002-9763-3298
}

\section{Інесса Візнюк}

доктор психологічних наук, професор кафедри психології та соціальної роботи

Вінницький державний педагогічний університет

імені Михайла Коцюбинського

21001, Україна, м. Вінниця, вул. Острозького, 32

innavisnjuk@gmail.com, https://orcid.org/0000-0001-6538-7742

\begin{abstract}
Анотація
Метою статті є обгрунтування методів психологічної реабілітації психосоматичних хворих працездатного віку. Методи дослідження: морфологічний тест життєвих цінностей в інтерпретації В. Сопова та Л. Карпушина для діагностики життєвих цінностей особистості; Вісбаденський опитувальник за методом позитивної та сімейної психотерапії (WIPPF); Гіссенський опитувальник соматичних скарг; «Чотиривимірний опитувальник для оцінки дистресу, депресії, тривоги та соматизації». Клінічний діагноз іпохондричних розладів було констатовано згідно 3 дослідницькими психодіагностичними критеріями в розділі міжнародної класифікації хвороб 10-го перегляду (МКX-10: клас V. Розлади психіки та поведінки) й DSM-V діагностичних критеріїв. Використано також метод експертних оцінок і бесіду (структурне інтерв’ю за Отто Кернбергом). До критеріїв психосоматичної відповідності оптимального стану функціонування організму в досліджуваних відносимо когнітивний, фізіологічний та поведінковий. Результати: представлено складові моделі «Психологічна реабілітація психосоматичних хворих працездатного віку», яка підкреслює зміст, форми, методи організаційно-методичних засад формування готовності фахівців до професійної самореалізації й безпеки життєдіяльності. Висновки: об'єктивність під час обгрунтування теми забезпечувалася шляхом реалізації неупереджених, некон'юнктурних узагальнень, зумовлених поглядами попередніх дослідників і перевіреної інформації з достовірних джерел. Психокорекційна робота була спрямована на посилення особистісного превентивного ресурсу й включала комплекс заходів, спрямованих на підвищення рівня когнітивного, емоційного й поведінкового інтелекту та пізнавально-базового, пропедевтично-ціннісного, узагальнювально-корекційного й конструктивно-процесуального критеріїв. Представлено рівні відповідності критеріям психосоматичного здоров'я в респондентів, характерними дисфункціями якого $\epsilon$ монотонні, емоційно примітивні скарги, які підкріплюються комплектом документів, накопичених за період обстежень.
\end{abstract}

Ключові слова: психологічна реабілітація, психокорекційна програма, психосоматичні розлади, психодіагностичні критерії, стан оптимального функціонування людини. 


\section{Вступ}

Високий рівень світових стандартів і вимог щодо будь-якої професійної діяльності вимагає від людини не тільки виконання обов'язків, володіння уміннями та навичками, але й професійності, освіченості, відповідальності, психологічної стійкості, надійності та ефективності професійної діяльності фахівців. За даними англійського психолога й соціолога Л. Кларка, втрата здоров'я й працездатності через іпохондричні захворювання відбувається в межах 40-50 років, що веде до значних економічних і соціальних втрат для суспільства.

Нині помітно зростає захворюваність й поширеність розладів психіки, зумовлених скаргами психосоматичного характеру в аспекті непсихотичних патологічних станів, невротичних розладів соматоформного типу, що потребують медико-психологічної допомоги. Спостерігається фіксована більш виражена негативна динамічність у розвитку соматичних захворювань, етіопатогенетична роль походження яких грунтується на психосоматичному та психогенному механізмах зародження (G. Beketova, G. Mozgova, O. Shekera, N. Beketova \& L. Stephania, 2019).

Психосоматичне здоров'я особистості відображає факт гармонійного залучення, приєднання людини до соціокультурної реальності, дозволяє зберігати психологічну рівновагу, дотримуватися життєвих перспектив. У працях В. Ананьєва, І. Аршави, С. Кулакова, Л. Кулікова, Г. Ложкіна, С. Максименка, І. Малкіної-Пих, В. Менделевича, Н. Пезешкіана, Г. Старшенбаума та ін. зазначається, що збереження психосоматичного здоров'я особистості $\epsilon$ актуальною проблемою, розв'язання якої означає досягнення особистістю гармонійного розвитку, підтримання оптимального психофункціонального стану в реалізації власного творчого пошуку та професійних надбань (Візнюк, 2019).

У процесі цілеспрямованої діяльності людина набуває специфічних властивостей i якостей самоактуалізації, самоорганізації, саморегуляції, самоконтролю, які визначають іiі особистісну стійкість у подоланні труднощів, що підтверджують у своїх наукових працях К. Абульханова-Славська, Б. Ананьєв, А. Брушлінський, Л. Виготський, Є. Клімов, О. Леонтьєв, Б. Ломов, С. Рубінштейн та ін. Саме тому ключовою ідеєю статті є обгрунтування важливості психологічної реабілітації психосоматичних хворих працездатного віку.

Впровадження відновлювальних заходів психологічної реабілітації для осіб працездатного віку з психосоматичними розладами свідчитиме про завчасну реалізацію й ефективність психокорекційної програми, 3 урахуванням диференціації механізмів їх виникнення. Врахування особливостей психосоматичних розладів у осіб різної професійної спрямованості сприятиме готовності фахівця до стресу й конфліктних ситуацій. Психокорекція міститиме перелік тренувальних вправ, орієнтованих на розвиток самопізнання, підвищення психологічної культури, вдосконалення рефлексивних характеристик особистості, самоактуалізацію й передбачатиме оволодіння навичками довільної психофізичної саморегуляції стану.

Метою дослідження $є$ обгрунтування методів психологічної реабілітації психосоматичних хворих працездатного віку. Повноцінна життєдіяльність людини характеризується прагненням розвиватись, наявністю якостей особистості, які сприяють саморозвитку та можливій самореалізації в професійній діяльності. Серед основних завдань нашого дослідження було: 1) теоретично дослідити та обгрунтувати методи психологічної реабілітації психосоматичних хворих працездатного віку; 2) визначити психологічні особливості формування особистості під час прояву психосоматичної хвороби в порівнянні 3 контрольними групами осіб; 3) розробити модель «Психологічна реабілітація 
психосоматичних хворих працездатного віку», яка розкриває зміст, форми, методи організаційно-методичних засад формування готовності фахівців до професійної самореалізації й безпеки життєдіяльності.

Стійкість у подоланні труднощів, збереження віри в себе, впевненості в собі, своїх можливостях, досконалість психічної саморегуляції - невід'ємна частина психічного життя. Здатність зберігати постійний рівень настрою, відчувати емоційну насиченість життя, мати різносторонні інтереси, полімотиваційність життєдіяльності - ознаки гармонійного характерологічного статусу людини (Візнюк, 2019).

Термін «психологічна реабілітація» отримав останнім часом міжнародне визнання й поширеність. За визначенням Всесвітньої організації охорони здоров'я (ВООЗ) концептує поняття психологічної реабілітації як активного процесу повного відновлення психосоматичного самопочуття людини внаслідок захворювання чи травм або ж оптимальну реалізацію психічного, фізичного та соціального потенціалів потерпілих, що найбільш адекватна їх інтеграції в суспільство (Вітенко, 2007).

Психологічна стійкість забезпечується низкою особистісних, фізіологічних i соціальних чинників. Як стверджує Г. Нікіфоров, її значимість проявляється в таких критеріях психологічного та соціального здоров'я: моральність (чесність, справедливість), відчуття вдячності, безкорисливості, відповідальності за себе та інших, а також у таких особистісних якостях як самоконтроль, врівноваженість, оптимізм, здатність планувати та реалізувати свій життєвий шлях тощо. Неадекватність і дезінтеграція внутрішньої особистісної регуляції сприяють розвитку таких психологічних порушень як безсердечність (жорстокість), безвідповідальність, агресивність, відчуженість, ігнорування соціальних норм, схильність до звинувачення оточуючих у своїх поразках, що дезактивує власну необачність, егоцентричність, маскування, образливість і маніпулятивну поведінку (Візнюк, 2019).

За визначенням Всесвітньої організації здоров'я (ВОO3) загальне здоров'я - це стан людини, якому властиве не тільки відсутність хвороби чи фізичних дефектів, але й повне фізичне, духовне та соціальне благополуччя. Для здоров'я найбільш типовими є такі основні ознаки як: структурна й функціональна збереженість систем і органів людини; індивідуальна висока адаптація організму до типового для нього фізичного та соціального середовища; збереження особистісного самопочуття, яке $\epsilon$ стимулом духовного й соціального благополуччя (Спіріна \& Вітенко, 2008).

Розглядаючи особливості соціально-психологічної дезадаптованості респондентів у аспекті формування внутрішньої картини хвороби, зазначимо про існування певних типів ставлення до порушення цілісності організму людини:

$>$ сенситивний (надмірна емоційна вразливість, страх щодо власної неповноцінності, недієздатність);

$>$ тривожний (безперевні хвилювання з приводу стану оптимального функціонування організму, перебігу хвороби та їі наслідків, пошук нових методів лікування, додаткової літератури тощо);

> меланхолійний (зневіра в компетентність лікарів, у одужання, в процес лікування, суїцидальні наміри);

$>$ апатичний (байдужість до хвороби, до свого майбутнього, втрата інтересу до життя, апатія в міжособистісних стосунках);

$>$ неврастенічний (спалахи роздратування в разі больових проявів, невірного лікування); 
$>$ егоцентричний (прийняття хвороби в пошуку вигоди для себе, виставлення напоказ своїх страждань, маніпулювання скаргами задля співчуття);

$>$ паранояльний (екстернальний підхід щодо розвитку хвороби, звинувачення інших у їі розвитку, надмірна підозрілість, скарги на зурочення чи карму);

$>$ анозогностичний (активне уникнення думок про хворобу, заперечення іï наявності, відмова від медичного лікування й обстеження);

$>$ дисфорійний (озлоблений настрій, незадоволений вигляд, підвищені вимоги щодо власної персони);

$>$ ергопатичний (втеча від хвороби в роботу, селективне ставлення до лікування з метою за будь-яких обставин продовжувати роботу);

> гармонійний (адекватна оцінка свого стану, розумна зацікавленість у лікуванні, переключення уваги на більш досяжну діяльність) (Вітенко, 2007).

Внутрішня картина хвороби відображає схильність людини до конфліктності, а особливо в разі наявності латентного перебігу внутрішньоособистісних розбіжностей, спровокованих психосоматичними скаргами. Зазвичай вони проявляються у вигляді конверсійних симптомів, соматоформних розладів, функціональних синдромів, соматизованих розладів, психосоматичних i дисморфофобічних реакцій. Кожен із них приносить людині первинну та вторинну вигоду (Малкіна-Пих, 2005). Первинна корисність полягає у тому, що ці прояви не активують внутрішній конфлікт у свідомості. Вторинна корисність - у тому, що симптоми дозволяють безпосереднім шляхом задовольняти власні актуальні потреби (стражденний вигляд завжди схиляє оточуючих до співчуття й уваги ближніх).

\section{Методи дослідження}

Психодіагностичний інструментарій дослідження склали такі взаємопов'язані наукові методи: «Морфологічний тест життєвих цінностей МТЖЦ» (в інтерпретації В. Сопова та Л. Карпушина) - для діагностики життєвих цінностей особистості; «Вісбаденський опитувальник за методом позитивної психотерапії та сімейної психотерапії (WIPPF)» (авт. Н. Пезешкіан (адапт. Л.Сердюк)); Гіссенський опитувальник соматичних скарг; «Чотиривимірний опитувальник для оцінки дистресу, депресії, тривоги та соматизації» (Тhе Four-Dimensional Symptom Questionnaire - 4DSQ). Клінічний діагноз іпохондричних розладів було констатовано згідно з дослідницькими психодіагностичними критеріями в розділі міжнародної класифікації хвороб 10-го перегляду (МКX-10: клас V. Розлади психіки та поведінки) й DSM-V діагностичних критеріїв. Використано також метод експертних оцінок i бесіду (структурне інтерв’ю за Отто Кернбергом). До критеріїв психосоматичної відповідності оптимального стану функціонування організму в досліджуваних віднесено когнітивний, поведінковий та фізіологічний компоненти (табл. 1).

Контрольні групи (КГ) (194 особи) представлені вибіркою здобувачів освіти Вінницького державного педагогічного університету імені Михайла Коцюбинського, 3 урахуванням їх генетичної схильності до проявів цієї нозоології. Експериментальні групи (ЕГ) склали фахівці різних професій, диференційованих за класифікацією О. Клімова (260 осіб), які в умовах виконання обов'язків переживали симптоматичні ознаки психосоматичної поведінки й проходили лікувально-відновлювану терапію у Вінницькій обласній клінічній лікарні імені ВОКЛ М. Пирогова та Вінницькій обласній психоневрологічній лікарні імені академіка О. Ющенка. 
Експериментальна робота здійснювалася в три етапи.

На першому emani (2018-2019 н. р.) був здійснений констатувальний психодіагностичний експеримент для визначення вихідних рівнів сформованості психосоматичної відповідності в осіб, які беруть участь у дослідженні.

На другому етапі (2019-2020 н.р.) здійснений формувальний психологічний експеримент, у якому перевірялися показники щодо психосоматичної відповідності в осіб працездатного віку.

На третьому етапі (2020-2021 н. р.) проводився аналіз показників за результативністю порівняльного експерименту у висновках щодо психосоматичної відповідності оптимального стану функціонування організму в досліджуваних.

\section{Результати та дискусії}

Відмітимо, що в досліджуваних ЕГ граничний характер показників мають такі параметри як замкнутість, спричинена недовірою до терапевтичного лікувального процесу та медичного персоналу (21\%), педантичність (16,8\%), довірливість $(14,7 \%)$, надмірна пунктуальність (14,7\%) або тї відсутність (9,1\%), недбалість (14\%), непостійність поведінки та вчинків, емоційна лабільність, безпідставна роздратованість (14\%), неакуратність (11,2\%), ритуалізована охайність $(8,4 \%)$, надмірна чутливість до чужого горя $(5 \%)$, залежність від чужої думки, конформність (10,8\%). Перелічене сигналізує про глибокі соціальні та внутрішньоособистісні конфлікти, здатні спричинити психосоматичні розлади дихальних шляхів, серцево-судинної та ендокринної систем, шлунково-кишкового тракту, шкірних покривів тощо.

Слід зазначити, що особи КГ і ЕГ не виявили суттєвих відмінностей у таких сферах як відчуття материнства $(41,2 \%)$ й батьківства $(20,6 \%)$, та в такій характерологічній особливості як терпеливість $(38,2 \%)$.

Таблиия 1

Критерії психосоматичної відповідності в осіб працездатного віку

\begin{tabular}{|c|c|c|c|c|c|c|}
\hline \multirow{2}{*}{$\begin{array}{c}\text { Критерії } \\
\text { психосоматичної } \\
\text { відповідності }\end{array}$} & \multicolumn{3}{|c|}{ ЕГ (260 осіб) } & \multicolumn{2}{c|}{ КГ (194 осіб) } \\
\cline { 2 - 7 } & До експерименту & Після експерименту & \multicolumn{2}{c|}{ До експерименту } \\
\cline { 2 - 7 } & Кі-ть & $\%$ & Кі-ть & $\%$ & Кі-ть & $\%$ \\
\hline Когнітивний & 86 & 20,89 & 92 & 31,34 & 61 & 32,62 \\
\hline Фізіологічний & 88 & 35,32 & 122 & 33,33 & 65 & 34,76 \\
\hline Поведінковий & 86 & 43,78 & 88 & 35,32 & 68 & 40,11 \\
\hline$\chi^{2}$ етр & \multicolumn{2}{|c|}{0,2370} & \multicolumn{3}{|c}{0,4655} & \multicolumn{2}{c|}{0,4247} \\
\hline
\end{tabular}

Проте, особливістю осіб ЕГ є те, що в разі виникнення проблем, вони втрачають самоконтроль і самовладнання (72\%), схильні до втечі в роботу $(9,1 \%)$, заперечують свої фізичні вади. Типові девіаційні зрушення фіксуємо у хворих із розладами травної, нервової та ендокринної систем - неадекватне та неконтрольоване вживання їжі під час стресу. В осіб із ішемічною хворобою серця спостерігаємо тенденції до надмірної пунктуальності та старанності. Хворі на ревматизм переважно переймаються проблемами ввічливості, порядку, справедливості та вірності. Для осіб із психосоматичним ураженням шкірних покривів характерна дезадаптація в соціальній сфері, особливо в комунікації.

Відзначимо також, що хворі з серцево-судинними скаргами, порівняно із здоровими особами, мають значно вищий рівень дезінтеграції між життєвими потребами та доступністю 
в різних сферах існування, ступінь та варіації девіантних проявів, рівень депресії; значно нижчий рівень психологічної стійкості; неадекватне завищення соціальної значущості хвороби в таких сферах: матеріальні збитки, обмеження задоволень, формування відчуття непотрібності, обмеження відчуття сили та енергії, погіршення ставлення до хворого в сім'ї, погіршення ставлення до хворого на роботі, обмеження кар'єрного росту; низький рівень професійної ідентичності.

Встановлено, що найвагомішим чинником психосоматичних порушень був соціальний стрес: проблемні взаємини в професійній сфері, зокрема, професійна нереалізованість (робота не за фахом, вимушена діяльність, безробіття тощо), міжособистісні конфлікти із керівником та 3 колективом, побутові проблеми. Другою за важливістю причиною виникнення кардіосимптомів, як ми 3'ясували, $є$ емоційний дискомфорт у сім’ї та сімейні стреси: несприятливі стосунки з близькими, скрутне матеріальне становище, відсутність надійної опори, розлучення, смерть близької чи рідної людини.

Виявлено, що ядром особистості осіб, хворих на психосоматичні захворювання, є прагнення до лідерства, соціальної переваги, сприймання життя як арени конкурентної боротьби, потужна орієнтація на перемогу за будь-яку ціну, актуальне бажання бути першими у всьому, особливо в професійній сфері, понаднормативна активність, нестриманість у прояві почуттів, наполегливість, настирливість, нетерплячість у досягненні мети.

Дослідження ми здійснювали в аспекті порівняння результатів експериментальної роботи, внаслідок чого було створено п'ять дослідних груп: ЕГ 1 складалася 347 осіб, ЕГ $2-55$ осіб, ЕГ 3 - 49 осіб, ЕГ 4 - 53 осіб, ЕГ 5 - 56 осіб. На контрольну групу осіб не здійснювалися психокорекційні впливи за зразком нормативів їх відповідності психосоматичного стану в умовах їх генетичної схильності до психосоматозів.

Аналіз даних, здобутих у передекспериментальному зрізі психодіагностичного вимірювання «До» та «Після» експерименту (рис. 1), дозволяє зазначити домінування низького та середнього рівнів сформованості психосоматичної відповідності нормативам психофункціональної дієздатності респондентів.

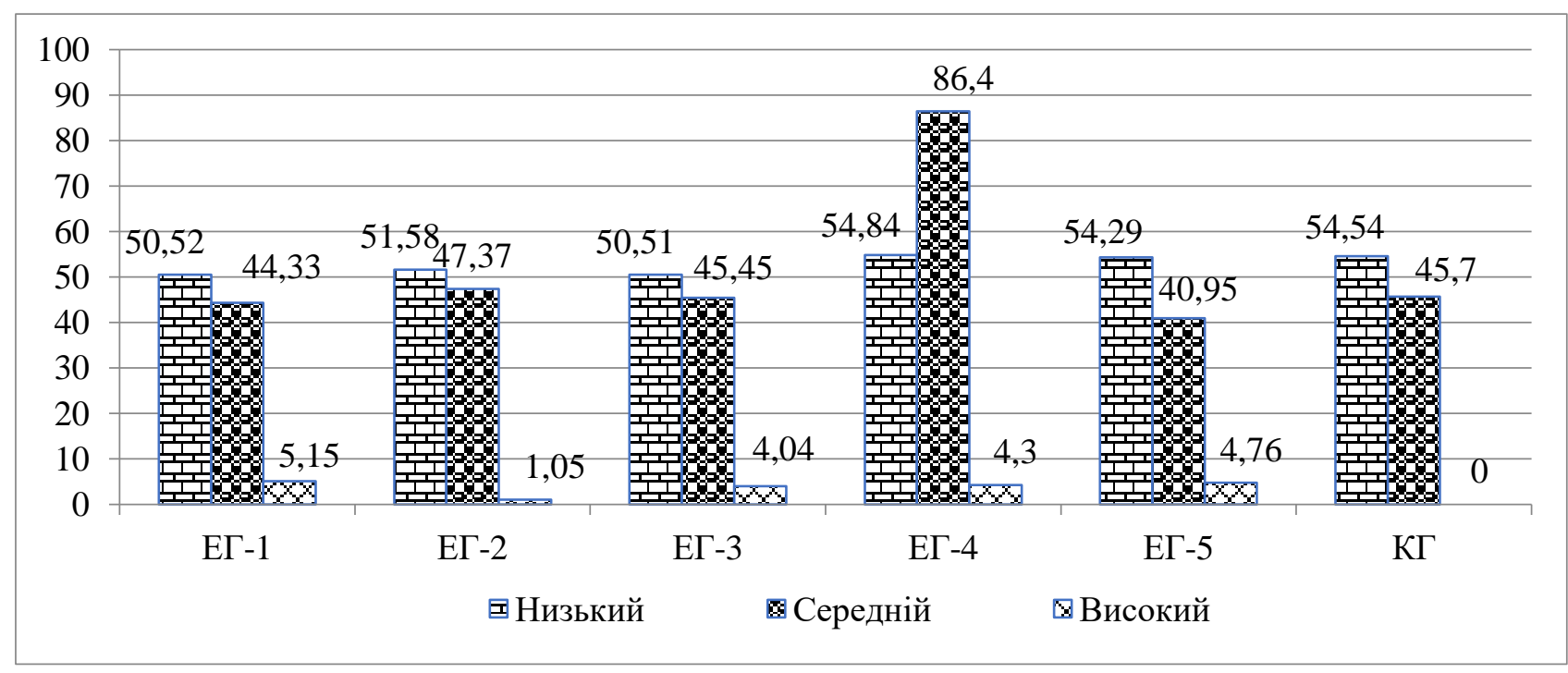

Рис. 1. Оцінювання рівнів сформованості психосоматичної відповідності респондентів на передекспериментальному зрізі 
Критерій $\chi^{2}$ К. Пірсона (на рівнях значущості 0,01 і 0,05) підтвердив, що між дослідними групами відсутні статистично значущі відмінності в сформованості значень рівня психосоматичної відповідності на початковому етапі в оцінці загального оптимального стану функціонування організму людини, оскільки всі обраховані значення $\chi_{\text {ennip. }}^{2}$ менші критичних

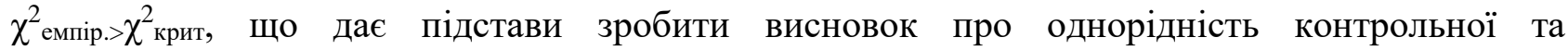
експериментальних груп на констатувальному етапі експерименту.

Особистісною відмінністю в КГ досліджуваних є прагнення до стабілізації й почуття відповідальності за свої вчинки, родину, друзів тощо. Вони є доброзичливими господарями, носіями миролюбних i дипломатичних цінностей, що виокремлює їх як спокійних $\mathrm{i}$ врівноважених трударів, які підтримують традиції своєї справи. Нижчі показники $\left(\chi^{2}=2,92\right.$, $\mathrm{p} \leq 0,003$ ) у осіб ЕГ свідчать про недостатню організацію своїх умінь, енергії та можливостей. Вони відрізняються невизначеністю в поглядах, оскільки не підтримують постійності у вчинках, професійній діяльності та в особистому житті. Зокрема, керуються переважно відчуттями, інтуїцією та світобаченням інших людей. В осіб контрольної групи незалежність при виконанні певної діяльності проявляється в процесі прийняття власного рішення й відповідальності на основі діалогічної взаємодії. Останнім притаманні такі особистісні характеристики як життєва мудрість, відкритість, комунікативність, практичність, що свідчить про потенціал психологічного здоров'я, готовність до ризику. Досліджувані ЕГ відзначились низькою активністю в сфері міжособистісних стосунків, що дезорганізовує їх поведінку в системі комунікацій і підкреслює схильність до інтроверсії.

Загалом представимо показники респондентів, які визначають систему смислової регуляції життєдіяльності особистості, яку встановлено за t-критерієм Ст'юдента - середні значення контрольної вибірки значущо вищі за середні значення експериментальної вибірки: «цілі в житті» $(\mathrm{t}=2,21, \mathrm{p} \leq 0,05)$, «насиченість життя» $(\mathrm{t}=3,62, \mathrm{p} \leq 0,001)$, «задоволеність самореалізацією» $(\mathrm{t}=3,14, \mathrm{p} \leq 0,005)$, «локус контролю - Я» $(\mathrm{t}=2,38, \mathrm{p} \leq 0,05)$ та «локус контролю - життя» $(\mathrm{t}=2,17, \mathrm{p} \leq 0,05)$.

Досліджувані ЕГ проявили переважно песимістичні погляди на життя: відсутність бажань, мрій, інтересу до подій, які відбуваються, безперспективне майбутнє тощо. Зазначимо, що стриманий гнів, пригнічена ворожість, будь-які невиражені агресивні тенденції особистості сприяють розвитку таких хвороб як гіпертонічна хвороба, цукровий діабет, тиреотоксикоз, гастродуоденіт. Крім того, заблоковані та нереалізовані прагнення до визнання, успіху, уваги оточуючих, задоволення від сексуальних потреб викликають підвищення активності холінергічних структур і сприяють розвитку бронхіальної ядухи, виразкової хвороби, шкірних патологій. Отже, зрозумілий взаємозв'язок проблем із соматичним здоров'ям особистості та емоційним виснаженням, нереалізованими мріями, розчаруванням у власних можливостях, залежністю від оточуючих людей, обставин, подій. За отриманими даними в шкалі життєвих цілей у психосоматичних хворих виражений акцент на минулому (92\%), незадовільна самореалізація, невіра у власні сили, безконтрольність, фаталізм.

Діагностику рівня сформованості психосоматичної відповідності респондентів на завершальному етапі психологогічного експерименту ми здійснили в травні 2020 р. (рис. 2).

У ЕГ у досліджуваних помітно підвищився рівень психосоматичної відповідності (22\%) щодо критеріїв здоров'я й життєдіяльності людини. Критерій $\chi^{2}$ К. Пірсона (на рівнях значущості 0,01 і 0,05) підтвердив, що між дослідними групами $є$ статистично значущі відмінності в сформованості значень рівня психосоматичної відповідності та відсутність скарг соматоформного типу, що свідчить про приналежність до показників контрольної групи осіб. 
Нульова гіпотеза відхиляється, оскільки всі обраховані значення більші критичних

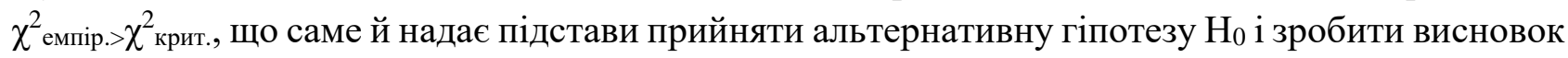
про ефективність психокорекційної програми на завершальному етапі дослідження в ЕГ.

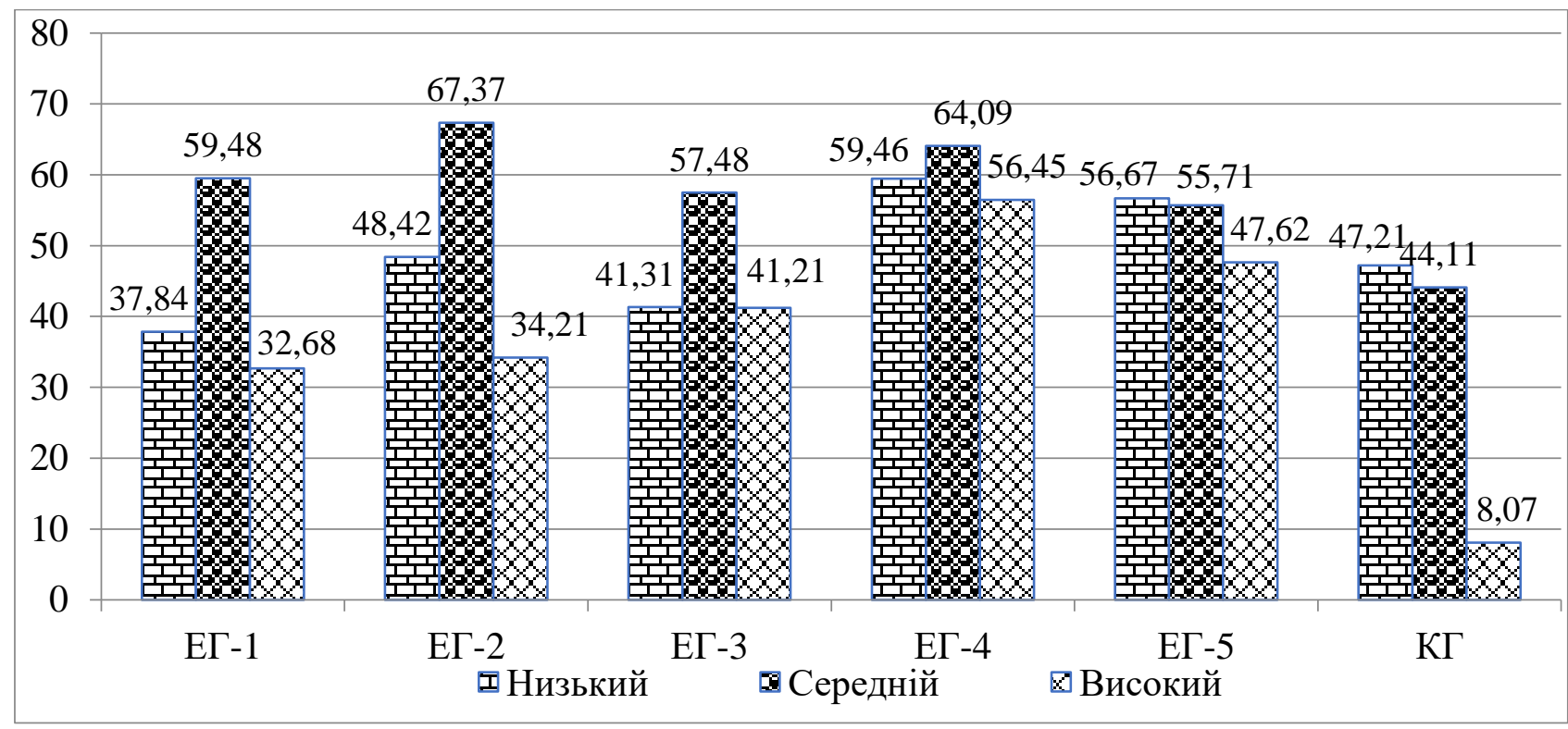

\section{Рис. 2. Оцінювання рівнів сформованості психосоматичної відповідності респондентів на завершальному етапі експерименту}

Аналіз отриманих даних критерієм $\chi^{2}$ Пірсона засвідчує наявність достовірних різниць $\left(\chi^{2}=16,87, p \leq 0,01\right)$ середніх показників психосоматичної відповідності досліджуваних КГ та ЕГ. Відзначимо, що сила й глибина психосоматичних розладів зумовлені індивідуальними психологічними характеристиками особистості, рівнем психологічного розвитку, поведінковими стереотипами й особливостями самоактуалізації, специфічною реакцією на ситуацію, способом переробки внутрішньоособистісного конфлікту, ступенем стресостійкості. За результатами нашого дослідження зв'язок між нервово-психічною стійкістю та психічним здоров'ям існує, він значущий і прямий $\left(\mathrm{r}_{\mathrm{xy}}=0,359, \mathrm{p} \leq 0,01\right)$. Це здійснювалося завдяки аналізу кількісних статистичних даних і всієї сукупності залучених джерел.

Отже, результати, представлені вище, свідчать про вплив на психосоматично здорових осіб загальнолюдських цінностей, які визначають сенс життя та стабільність психічних структур особистості. Експериментальні дані виявляють суттєво вищу адаптованість осіб КГ та їх раціональний підхід до життєтворення. Саме тому, психокорекційна робота була побудована на формуванні позитивних характерологічних тенденцій гармонійної особистості. Результати формувального експерименту не є предметом даної статті, проте зазначимо, що запропонований підхід дав достатньо високі результати $(\mathrm{t}=0,27 ; \mathrm{p} \leq 0,01)$.

При плануванні допомоги щодо вищезазначених проблем психосоматичного характеру в працездатних осіб, варто розкрити особливості психокорекційного підходу. Дослідженням у галузі психології здоров'я в зв'язку 3 представленими завданнями щодо терапії та профілактики цих розладів необхідно опиратись на такі психодіагностичні основи:

1. Використання багаторівневого мультимодального підходу, інтегрованого зі сторін саногенетичних та патогенетичних взаємовпливів процесу розвитку й тривалості 
захворювання. Цей підхід зумовлений такими рівнями (Любан-Плоцца, Пельдингер, Крегер \& Леденцах-Гофман, 2000):

соиіальний: вивчення соціального, професійного статусу, інтерперсональних взаємодій, сімейних відносин;

nсихологічний: вивчення преморбідних особливостей особистості, індивідуальної структури хворого, способів психологічного захисту, копінг-поведінки, поведінки в ситуаціях фрустрації, ставлення до хвороби;

$>$ nсихосоматичний: вивчення генетичної спадковості, соматичного та нейрогормонального статусу у взаємозв'язку із соціально-психологічними параметрами;

$>$ типологічний: виділення та вивчення психосоматичних типів і психологічного портрета особистості в умовах професійного забезпечення;

$>$ синдромологічний: виділення й вивчення провідних синдромів і скарг зародження та розвитку іпохондричних розладів особистості;

$>$ nсихотерапевтичний: використання психотерапевтичних методів у комплексному лікуванні психосоматичних хворих;

профілактичний: розробка програм для первинної, вторинної профілактики та реабілітації хворих.

2. Використання методу секторного дослідження (Мозгова, 2019), а саме:

виділення і вивчення генеральних рис особистості та їх гормонального забезпечення в залежності від найбільшої вегетативної реактивності;

вивчення не тільки індивідуальних рис, але й їх кореляцій, тобто симптомокомплексів (у структурі особистості іпохондричних хворих відсутній монобазис);

вивчення сформованого із симптомокомплексів типу особистості (дослідження взаємозв'язків між рисами й цілісністю людини, тобто взаємовідносин людини з її світом);

вибір динамічних і перспективних методів як найбільш продуктивних;

використання методів моделювання в наукових дослідженнях психосоматичних співвідношень тощо.

Психокорекційна робота щодо подолання психосоматичних розладів особистості була спрямована на посилення особистісного (індивідуального) превентивного ресурсу й включала комплекс заходів, спрямованих на підвищення рівня когнітивного, емоційного й поведінкового інтелекту.

Змістово-процесуальну складову моделі «Психологічна реабілітація психосоматичних хворих працездатного віку» представлено у вигляді низки професійних надбань, які підкреслюють зміст, форми, методи організаційно-методичних засад формування готовності фахівців до професійної самореалізації й безпеки життєдіяльності.

Модель психокорекції психосоматичних розладів особистості включала такі критерії: пізнавально-базовий, пропедевтично-ціннісний, узагальнювально-корекційний i конструктивно-процесуальний. Готовність майбутніх фахівців до професійної самореалізації передбачала під час формувального етапу експерименту використання таких педагогічних умов: формування мотиваційних установок у респондентів щодо професійної самореалізації засобами імітаційного моделювання; активізація пізнавальної діяльності студентів і фахівців працездатного віку засобами інформаційно-комунікаційних технологій.

Психокорекційна програма ПККПТ як складова цієї моделі містила комплекс тренувальних вправ, спрямованих на підвищення психологічної культури, розвиток самопізнання, самоактуалізацію, вдосконалення рефлексивних характеристик особистості, й 
передбачала оволодіння прийомами довільної психічної та психофізичної саморегуляції стану в досліджуваних. Психокорекційний комплекс поєднував прийоми саморегуляції емоційного стану, контролю та зміни соматичних проявів емоцій, прийоми нормалізації психоемоційного стану через фізичний стан тіла - вправи тілесної терапії, прийоми релаксації та зняття психологічних бар'єрів, техніки гармонійного дихання, психофізичне тренування тощо. Розвиток індивідуальних властивостей та психічних функцій особистості, що зумовлюють відновлення психосоматичного здоров'я, передбачав корекцію самооцінки, вивчення сильних сторін особистості, розвиток впевненості в собі, формування вольових якостей, тренування довільної уваги, візуалізацію тощо (Візнюк, 2019).

Реалізація й розробка програми позааудиторних заходів у здобувачів освіти КГ була спрямована на підготовку безпеки професійної самореалізації й створення рефлексивноорієнтованого середовища, яке передбачає застосування в освітньому процесі вищого закладу методики формування готовності респондентів до безпеки професійної самореалізації. Очікуваними результатами такого навчання було підвищення професійної компетенції фахівців щодо психосоматичних настроїв і безпеки їх життєдіяльності в умовах виконання обов'язків.

\section{Висновки}

Отже, висвітлення психологічних особливостей поведінки хворих на психосоматичні захворювання та їх корекція, здійснювалися поетапно шляхом впровадження моделі «Психологічна реабілітація психосоматичних хворих працездатного віку», яку представлено у вигляді низки професійних надбань, що підкреслюють зміст, форми, методи організаційнометодичних засад формування готовності фахівців до професійної самореалізації й безпеки життєдіяльності. Повноцінна життєдіяльність людини характеризується прагненням розвиватись, наявністю якостей особистості, які сприяють саморозвитку та можливій самореалізації в професійній діяльності. Визначення психологічних особливостей формування особистості під час прояву психосоматичної хвороби в порівнянні з контрольними групами осіб, що було основним завданням нашого дослідження, представлено в оцінюванні рівнів сформованості психосоматичної відповідності респондентів на доекспериментальному зрізі та завершальному етапі експерименту.

Впровадження корекційних заходів психологічної реабілітації в осіб працездатного віку та в студентів зі схильністю до психосоматичних розладів, показав свою ефективність і реалізовувався в рамках спеціальної психокорекційної програми, яка містила комплекс тренувальних вправ, спрямованих на розвиток самопізнання, підвищення психологічної культури, вдосконалення рефлексивних характеристик особистості, самоактуалізацію й передбачала використання прийомів довільної психофізіологічної саморегуляції стану.

Перспективу подальших досліджень ми вбачаємо в розробці практичних рекомендацій викладачам освітніх закладів України щодо використання моделі психологічного забезпечення щодо психосоматичних скарг у здобувачів вищої освіти на засадах проблемного навчання. 


\section{Література}

1. Візнюк, I.M. (2019). Психосоматичні кореляти в аспекті розвитку іпохондричної поведінки особистості. Психологічний часопис, 8(7), 174-188. doi:10.31108/1.2019.5.8.11

2. Любан-Плоцца, Б., Пельдингер, В., Крегер, Ф., $\quad \& \quad$ Леденцах-Гофман, К. $\quad$ (2000). Психосоматические расстройства в общей медиџинской практике. Санкт-Петурбург : Издание Института Бехтерева, 2000.

3. Малкина-Пых, И.Г. (2005). Психосоматика: Справочник практического психолога. Москва : Издательство «Эксмо».

4. Спіріна, І.Д., \& Вітенко, І.С. (2008). Медична психологія: підручник Дніпропетровськ : АРТпрес.

5. Менделевич, В.Д. (2005). Клиническая (медиџинская) психология. (с. 3-61) Москва : МЕДпресс-информ.

6. Beketova, G., Mozgova, G., Shekera, O., Beketova N., \& Stephania, L. (2019). Neurophysiological characteriscs of psychosomatic disorders and psychosomatic pathology in children and adolescents. Wiadomości Lekarskie is abstracted and indexed in: SCOPUS, T.LXXII, 12(I), 2282-2288. Режим доступу:https://wiadlek.pl/wp-content/uploads/2020/02/

WL-12-cz-II-2019.pdf

\section{References}

1. Viznyuk, I.M. (2019). Psychosomatic relations in the aspect of development of the hypochondriacal behavior of the individual [Psychosomatic correlates in terms of the development of hypochondriac personality behavior]. Psykholohichnyi chasopys - Psychological hour, 8 (7), 174-188. doi:10.31108/1.2019.5.8.11 [in Ukrainian]

2. Liuban-Plotstsa, B., Peldynher, V., Kreher, F., \& Ledentsakh-Hofman, K. (2000). Psykhosomatycheskye rasstroistva $v$ obshchei medytsynskoi praktyke [Psychosomatic disorders in general medical practice]. Saint Petersburg: Publishing of the Bekhterev Institute [in Russian].

3. Malkyna-Pukh, Y.H. (2005). Psykhosomatyka: Spravochnyk praktycheskoho psykholoha [Psychosomatics: A Practical Psychologist's Handbook]. Moscow : Izdatelstvo "Eksmo" [in Russian].

4. Spirina, I.D., \& Vitenko, I.S. (2008). Medychna psykholohiia: pidruchnyk. [Medical psychology: textbook]. Dnipropetrovsk : ART-pres [in Ukrainian].

5. Mendelevych, V.D. (2005) Klynycheskaia (medytsynskaia) psykholohyia [Clinical (medical) psychology] (pp. 3-61). Moscow : MEDpress-inform [in Russian].

6. Beketova, G., Mozgova, G., Shekera, O., Beketova N., \& Stephania, L. (2019). Neurophysiological characteriscs of psychosomatic disorders and psychosomatic pathology in children and adolescents. Wiadomości Lekarskie is abstracted and indexed in: SCOPUS, T.LXXII, 12 (I), 2282-2288. Retrieved from https://wiadlek.pl/wp-content/uploads/2020/02/WL12-cz-II-2019.pdf 


\title{
PSYCHOLOGICAL REHABILITATION OF PSYCHOSOMATIC PATIENTS OF WORKING AGE \\ Galyna Mozgova \\ Doctor of Sciences in Psychology, Professor, Head of the Department of Psychosomatics and Psychological Rehabilitation \\ National Pedagogical Dragomanov University \\ 9, Pyrohov Str., Kyiv, Ukraine, 01601 \\ gala_mozgovaya@ukr.net, https://orcid.org/0000-0002-9763-3298
}

\author{
Inessa Vizniuk \\ Doctor of Sciences in Psychology, Professor of \\ the Department of Psychology and Social Work
}

Vinnytsia State Pedagogical University named after Mykhailo Kotsyubynsky

32, Ostrozkogo Str., Vinnytsia, Ukraine, 21001

innavisnjuk@gmail.com, https://orcid.org/0000-0001-6538-7742

\begin{abstract}
The purpose of the article is to substantiate the psychological rehabilitation of psychosomatic patients of working age. Research methods: questionnaire MTZHTs (morphological test of living values); Wiesbaden Questionnaire (WIPPF), Giessen Somatic Complaints Questionnaire, "Four-dimensional questionnaire to assess distress, depression, anxiety and somatization". The clinical diagnosis of hypochondriac disorders was established according to research psychodiagnostic criteria in the section of the International Classification of Diseases 10th revision (MKH-10: class V. Mental and behavioral disorders). Expert assessment and interview (Structural interview with Otto Kernberg) were also used. The criteria of psychosomatic compliance with the optimal state of organism functioning in the study group include cognitive, physiological and behavioral ones. Results. The components of the model "Psychological rehabilitation of psychosomatic patients of working age" are presented, which emphasizes the content, forms, methods of organizational and methodological principles of forming the readiness of professionals for professional self-realization and safety. Conclusions. Objectivity in substantiating the topic was ensured by implementing unbiased, nonopportunistic generalizations based on the views of previous researchers, and verified information from reliable sources. Psycho-correctional work was aimed at strengthening personal preventive resources and included a set of measures aimed at improving the level of cognitive, emotional and behavioral intelligence and cognitive-basic, propaedeutic-value, generalizing-corrective and constructive-procedural criteria. The levels of compliance with the criteria of psychosomatic health in the respondents are presented, the characteristic disfunctions of which are monotonous, emotionally primitive complaints, which are supported by a set of documents accumulated during the survey period.
\end{abstract}

Keywords: medical and psychological rehabilitation, psychocorrection program, psychosomatic problems, psychodiagnostic criteria, optimal functioning of people. 